\section{BIOTECHNOLOGY:}

$r$

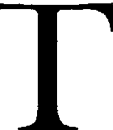

he Regulatory Affairs Professional Society (RAPS), an organization for regulatory affairs officers from the chemical, pharmaceutical, and medical device industries, sponsored an educational seminar titled "Biotechnology: The Regulatory Revolution" late last year. The seminar focused on regulatory issues facing companies using gene splicing and hybridoma technologies to produce diagnostic and therapeutic products. Speakers included representatives from the legal profession, the biotechnology industry, biotechnology consultants, and the Food and Drug Adminstration (FDA).

A. Ghignone (National Patent Development Corp.), the organizer of the seminar, began with a brief overview of the industry. G. Karney, an attorney and major contributor to the recent OTA report on biotechnology, then presented a detailed analysis of government regulation of biotechnology research and commercialization, stressing that industry's perception of the regulatory climate will strongly influence decisions about which biotechnological products will reach the marketplace. A vast array of federal regulations (e.g. those promulgated by FDA, EPA, USDA, and OSHA) affect the industry. Karney recommends voluntary industrial compliance with the NIH Guidelines for Recombinant DNA because the courts could consider the guidelines a minimum standard of practice. He suggested that exceeding the requirements would be a better idea to strengthen defense against inevitable product liability suits.

B. Merchant (Office of Biologics, FDA) explained FDA's position on monoclonal antibodies used for in vitro diagnostic products and in vivo diagnostics and therapeutics. Over 50 monoclonal antibody products have been approved for marketing as in vitro diagnostic reagents, and a comparable number are now in clinical trials for use as parenteral products. Merchant predicted that as many as 1000-2000 different monclonal antibodies could become useful diagnostic products, 100-200 may become useful for in vivo diagnostic applications, and 10-100 monoclonals will be incorporated into parenteral therapeutic products. Currently, all commercial monoclonal antibody products are of murine origin, but Merchant pointed out that the eventual use of human-human monoclonal antibodies is almost certain. He emphasized that the FDA is acutely aware of the evolving nature of cell

\title{
THE REGULATORY REVOLUTION
}

fusion technology and the potential diversity of its products. The FIA also recognizes that the heterogeneous nature of the companies that produce and market monoclonal antibodies results in many different levels of awareness of regulatory requirements. The agency realizes that the rapid evolution of this industry has led to some confusion and intends to continue its flexible stance with regard to applying its regulatory authority to the industry. For example, he cited the "Points to Consider" memoranda recently issued by the agency. These memoranda will serve as evolving and informal guidelines in the regulation of monoclonal antibody and other products derived from biotechnology.

D. Hill (Office of Biologics, FDA) explained the newly published FDA regulations for monoclonal antibodies. The Office of Medical Devices will regulate monoclonal antibody products intended for in vitro diagnostic use. The exceptions are monoclonalbased diagnostics that are used in conjunction with a FDA-licensed biologic product; these will fall under the jurisdiction of the Office of Biologics, which will also regulate monoclonal antibody products intended for in vivo diagnostic use. The FDA recognizes that a monoclonal antibody may well have multiple applications, and that manufacture of monoclonals is still a "cottage industry;" thus they will allow licensing of products made by divided manufacture. Hill also reported that FDA interest in monoclonal production begins at the ascites or tissue culture cell stage.

L. Millstein (Division of Drug Advertising and Labeling, FDA) expressed concern that many new biotechnology companies are not familiar with FDA regulations covering advertising. He noted that there can be a fine line between legitimate scientific exchange and advertising, and suggested the companies contact his office for advice in this complicated area.

Drawing on his 11 years of experience as a bureau director, $H$. Meyer, currently director of the FDA's National Center for Drugs and Biologics, provided a historical perspective on the evolution of both the FDA and the biotechnology industry. Dr. Meyer expressed concern about the ability of his agency to effectively regulate a rapidly growing industrial sector while the agency's resources are not growing, and suggested that organizational change within the agency is necessary for it to do its job well. $\mathrm{He}$ cited the "IND-NDA rewrite" stan- dards for new drugs and biologicals and the combining of the Bureau of Drugs and the Bureau of Biologics as two benefical reorganizations. $\mathrm{He}$ noted that the changes will strengthen both the agency's science base and its affiliations with other Health and Human Services agencies such as NIH. He also anticipates better communication with the Centers for Disease Control in developing the epidemiology activities at FDA. Dr. Meyer stressed that the FDA is anxious to increase its dialogue with the biomedical and industrial communities.

Audio casettes of the entire seminar are available from Audio Transcripts Ltd., 601 Madison Street, Alexandria, VA 22314.

Michael Gross, Ph.D., is Director of Regulatory Affairs for Triton Biosciences Inc. (formerly Applied Biosciences, Inc.), a subsidiary of Shell Oil Co., 901 Grayson Street, Berkeley, CA 94510.

BIOTECHNOLOGY

\section{/ the international JOURNAL FOR INDUSTRIAL BIOLOGY}

invites qualified researchers to submit

\section{RESEARCH NOTES}

for rapid publication of innovative research in the life sciences with industrial implications. The Research Notes section of the journal will be expanded in the future to include jourt reports from acade future to include short reports from acadernic and been made for accepted manuscripts to be printed, under usual circumstances, within six to ten weeks.

BIO/TECHNOLOGY may be the most widely circulated general journal for applied biological research. Each Research Note is refereed by distinguished reviewers in pertinent fields.

Research Notes are single concept papers which may not exceed 2,000 words and may include up to three figures or tables. An abstract of approximately 50 words should be included. The title should be descriptive of the contents of the paper and identify a che relevant discipline. The experiment should be integrated into the text along with the results section of the text. The list of references should be numbered sequentially and should appear in the following format: authors, year, full title, journal, volume, beginning and ending pages. Other rules of style should conform closely to the Council of Biology Editors Style Manual, Fourth Edition.

The original manuscript and three copies, a cover letter describing the novelty of the work and the names of three or more referees able to judge the merits of the work should be sent to:

Research Editor, BIO/TECHNOLOGY, 15 East 26th St., New York, N.Y. 10010 or Research Editor, BIO/ TECHNOLOGY, 4 Little Essex St., London WC2R 3LF, UK 